\title{
EFEKTIVITAS WEBLOG DAN FACEBOOK TERINTEGRASI UNTUK PEMBELAJARAN VIRTUAL
}

\author{
Hartono \\ Universitas Islam Sultan Agung Semarang \\ email: hartonotgo@gmail.com
}

\begin{abstract}
Abstrak: Saat ini, banyak mahasiswa menghabiskan waktu mereka di internet. Mereka melakukan kegiatan seperti membuat blog, mengunduh, mengunggah, chatting, dan berinteraksi melalui facebook. Mahasiswa sekarang ini hidup dengan teknologi. Penelitian menunjukkan bahwa weblog dan facebook berpotensi mendukung belajar dan mengajar. Guru dan pendidik menggunakan kegiatan tersebut untuk meningkatkan kualitas belajar. Penelitian ini bertujuan untuk mengetahui efektivitas weblog dan facebook ketika digunakan secara integratif untuk melengkapi pembelajaran. Penelitian ini menggunakan metode kuantitatif deskriptif. Data dikumpulkan dari halaman-halaman facebook yang diamati dari responden yang mengambil mata kuliah Introduction of Second Language Acquisition (SLA). Data kemudian dideskripsikan dan dianalisis. Temuan penelitian menunjukkan bahwa weblog dan facebook dapat digunakan secara efektif untuk melengkapi kegiatan belajar.
\end{abstract}

Kata Kunci: weblog, facebook, pembelajaran virtual

\section{THE EFFECTIVENESS OF INTEGRATED WEBLOG AND FACEBOOK IN VIRTUAL TEACHING}

\begin{abstract}
Nowadays, many students spend much of their time in the internet. They do activities such as blogging, downloading, uploading, chatting, and facebooking. Students today are living with the technology. Research shows that weblog and facebook potentially support learning and teaching. Teachers and educators use them to improve the quality of learning. This research aimed at finding out the effectiveness of weblog and facebook when they were integratedly used to supplement teaching. It used the descriptive quantitative method. The data were collected from the facebook pages under observation and from respondents who were taking the course of the Introduction of Second Language Acquisition (SLA). The data were described and analyzed. The findings suggested that the weblog and facebook could effectively be used to supplement learning.
\end{abstract}

Keywords: weblog, facebook, virtual learning

\section{PENDAHULUAN}

Pada saat ini, mahasiswa banyak menghabiskan waktu keseharian dengan internet (Top, 2012). Mereka melakukan blogging, mengunduh, dan mengunggah dokumen yang berupa teks, suara, gambar atau film, mengunakan facebook, twitter, youtube, permainan dalam jaringan (online games), dan lain-lain. Dengan kata lain, mahasiswa hidup bersama dengan teknologi ini (Robert, Foehr, \& Rideout, 2005). Pada saat yang sama, praktik pembelajaran dan pembelajaran di perguruan tinggi telah bergerak ke arah model pembelajaran yang terpusat pada mahasiswa (student-centered) dan berbasis ko- munitas (community-based) (Deng \& Tavares, 2013). Oleh karena itu, kini banyak dosen mulai memergunakan teknologi digital dalam proses pembelajaran untuk meningkatkan kualitas pembelajaran dan kepuasan mahasiswa.

Blog adalah kependekan dari weblog yang termasuk perangkat teknologi Web 2.0. Blog adalah jurnal berbasis web yang berisi gagasan dan atau pikiran seseorang yang disajikan dalam web untuk bisa dibaca dan diketahui banyak orang (Flatley, 2005). Dengan blog, pengguna dapat menggunakan laman untuk jurnal pribadi dan artikel, data, gambar dan bahkan film yang bisa dibagi dengan masyarakat. Pascu 
(2008) menyatakan bahwa jumlah blog tumbuh dengan cepat dan menjadi sangat populer yang mencakup banyak sekali bidang, seperti bisnis, kesehatan, olahraga, dan pendidikan. Dalam bidang pendidikan, pemanfaatan blog juga sangat beragam, seperti penelitian, pembelajaran ilmu tertentu seperti statistika, biologi, fisika, bahasa asing, filsafat, pemecahan masalah dan soalsoal, sampai dengan penyuaraan aspirasi kelompok-kelompok tertentu dalam bidang pendidikan.

Banyak penelitian menunjukkan bahwa blog dapat dimanfaatkan sebagai media pembelajaran dan pengajaran yang efektif (Top, 2012). Ellison \& Wu (2008) meneliti tentang persepsi mahasiswa terhadap pemanfaatan blog dan menemukan bahwa mahasiswa menikmati blogging. Blog juga bisa meningkatkan tingkat kemandirian belajar mahasiswa dan pada saat yang sama memungkinkan dilakukannya interaksi yang lebih dalam antarmahasiswa (Williams \& Jacobs, 2004), meningkatkan dan mendukung pengalaman belajar individu (individual learning experience) (Lin, 2006), serta mendorong kemampuan berfikir terstruktur (Huffaker, 2005).

Sementara itu, facebook adalah jejaring sosial yang pertama kali dirancang oleh Mark Zuckerberg. Sejarah media sosial ini berawal pada February 2004, saat Zuckerberg meluncurkan situs ini untuk pertama kali. Dalam waktu 24 jam, 1.200 mahasiswa Harvard telah bergabung dan setelah 1 bulan lebih dari separo mahasiswa Harvard telah memiliki profil masing-masing di jejaring sosial ini. Jejaring ini kemudian dengan sangat cepat menyebar ke universitas-universitas lain di Amerika dan bahkan dunia. Situs ini dioperasikan dengan tidak berbayar, tetapi memperoleh keuntungan dari penghasilan iklan (Phillips, 2007).

Kini, facebook telah berkembang menjadi salah satu situs jejaring sosial dengan jumlah pengguna terbanyak dan telah menjadi bentuk jejaring sosial yang paling popular di antara anak-anak muda dan mahasiswa (Petrovic, Petrovic, \& Jeremic, 2012). Studi menunjukkan bahwa antara $85 \%$ sampai dengan $99 \%$ mahasiswa menggunakan facebook (Junco, 2011), dan lebih dari 90\% mahasiswa (usia 18 - 23 tahun) menggunakan facebook secara rutin setiap hari (Alhenshiri, 2011). Sebagai jejaring sosial, facebook mendukung aktivitas pendidikan (Selwyn, 2007), merangsang lebih banyak lagi interaksi antara dosen dan mahasiswa dan antara mahasiswa dan mahasiswa, serta mahasiswa bisa belajar lebih banyak (Pollara \& Zhu, 2011).

Studi ini meneliti tentang efektivitas weblog dan facebook yang dipergunakan untuk pembelajaran. Kedua media ini diintegrasikan. Weblog dosen pengampu mata kuliah diintegrasikan dengan facebook group yang secara khusus dibuat untuk mahasiswa peserta kuliah. Hal ini dilakukan karena meski banyak memberi manfaat, tidak semua mahasiswa tertarik untuk memiliki blog. Alasan lainnya adalah karena mengelola blog lebih rumit dan berbayar, khususnya untuk blog dengan kapasitas besar. Pemilik blog diharuskan membayar sewa domain yang dikenakan per tahun. Sementara itu, facebook adalah gratis dan sangat praktis, tetapi tingkat lalu lintas isi dalam bentuk posting cenderung tinggi sehingga informasi yang dipasang akan secara cepat tergeser secara kronologis dengan posting yang lebih baru.

Penelitian ini berpusat pada dua hal. Pertama adalah profil penggunaan facebook oleh responden. Kedua adalah manfaat integrasi media ini bagi mahasiswa, khususnya dalam meningkatkan kualitas pembelajaran mata kuliah yang sedang diambil oleh responden.

Secara ringkas, integrasi dapat dijelaskan sebagai berikut. Dosen membuat weblog yang berisi materi-materi dan hal-hal lain yang terkait dengan perkuliahan yang dilaksanakan. Weblog ini tentu saja bisa dihubungkan dengan weblog lain dengan pemberian tautan (links). Kemudian, dosen memuat account facebook dan group dan dosen menjadi administratornya sehingga dia bisa menentukan dan membatasi siapa saja yang bisa menjadi anggota group. Materi perkuliahan yang ada di weblog dosen selanjutnya dibagikan ke grup dengan fasilitas +Share yang sebelumnya telah dipasang di weblog, atau dengan cara memberikan tautan dari grup ke weblog dosen. 
Mahasiswa dan dosen melakukan aktivitas terkait pembelajaran dengan memanfaatkan aplikasi-aplikasi yang ada, seperti Write Post, Add Photo/Video, Ask Question, Add file, Like, Comment, maupun facebook page dan chronology. Aplikasi lain seperti Quiz, Video Streaming, Slideshare juga bisa dipasang di grup sehingga materi teks, suara, film, gambar, dan power point bisa disajikan secara mudah dan cepat. Untuk kepentingan quiz, dapat dipergunakan Question Writer yang bisa unduh dari http://www.questionwriter.com/. Setelah soal selesai dalam berbagai bentuk dibuat, soal ini kemudian dipublish dengan Question Writer Tracker, kemudian dibuatkan tautan di weblog dan dibagi (share) ke grup. Setiap kali mahasiswa selesai mengerjakan quiz, maka hasil dan detail quiz tersebut akan secara otomatis masuk ke surat elektronik dosen. Quiz bisa pula disajikan dengan aplikasi Quotev yang bisa ditelusur dan dipasang dari http://www.quotev.com/ yang bisa langsung dipasang di halaman facebook.

Dengan integrasi ini, kebutuhan pembelajaran seperti penyajian materi berupa teks, gambar, power point, audio-video, diskusi, komentar, quiz, dan lain-lain dapat dilakukan dengan mudah.

\section{METODE}

Penelitian ini merupakan penelitian deskriptif quantitatif yang mengikuti model Gall \& Borg (2005). Penelitian deskriptif quantitatif bertujuan untuk menjelaskan karakteristik yang melibatkan sampel dan populasi serta sangat tergantung pada data-data numerik dan analisis statistik. Subjek penelitian ini adalah mahasiswa Program Studi Pendidikan Bahasa Inggris Fakultas Bahasa Universitas Islam Sultan Agung (UNISSULA) Semarang yang sedang mengikuti mata kuliah Introduction to Second Language Acquisition pada Semester Genap Tahun Akademik 2012/2013 yang berjumlah 55 orang. Subjek ini dipilih secara purposif karena penulis pada semester itu sedang mengampu mata kuliah tersebut.

Mata kuliah dengan bobot kredit SKS tersebut membahas topik-topik antara lain
Language Learning vs. Language Acquisition, Krashen's Hypothesis, the Role of Teaching Grammar, the Role of Feedbacks, dan lain-lain. Perkuliahan ini menjadualkan 1x tatap muka di kelas selama 2 x 45 menit. Di luar pertemuan kelas secara terjadwal tersebut, dosen membuat facebook group yang khusus dibuat untuk mendukung perkuliahan. Group tersebut diberi nama SLA Colasula. Nama SLA diambilkan dari nama mata kuliah Second Language Acquisition, sedangkan Colasula adalah singkatan dari College of Language Sultan Agung yang merupakan terjemahan bahasa Inggris dari Fakultas Bahasa Universitas Islam Sultan Agung. Weblog yang dipergunakan adalah weblog peneliti yang diberi label Language Learning and Global Education yang ada pada laman www.colasula.com.

Aktivitas pembelajaran meliputi presentasi oleh dosen pengampu dan kelompok mahasiswa yang telah ditunjuk untuk menyajikan topik tertentu, diskusi serta tanya jawab. Aktivitas di blog meliputi posting tulisan (artikel) dan penyediaan tautan untuk penelusuran lebih banyak lagi informasi terkait topik yang dibahas. Posting pada blog hanya dilakukan oleh dosen pengampu, yang selanjutnya posting ini dibagi (share) ke dalam facebook group SLA Colasula. Aktivitas yang dilakukan mahasiswa meliputi mengunduh materi dari blog, bertanya, memberi komentar, mengunggah materi yang relevan di facebook group (berbagi bahan belajar), dan lain-lain.

Data dikumpulkan dari interaksi yang terjadi di laman facebook group mata kuliah SLA Colasula semester genap 2011/2012 dan laman facebook group mata kuliah yang sama pada semester genap 2012/2013. Alasan dipergunakan 2 kelompok mahasiswa yang berbeda ini adalah untuk menemukan ada tidaknya konsistensi dalam aktivitas pemanfaatan model ini. Data quesioner hanya dikumpulkan dari mahasiswa peserta kuliah SLA pada semester genap 2012/2013.

Quesioner mencakup lima bagian, yaitu: (1) identitas responden; (2) kepemilikan $a c$ count facebook dan blog oleh responden; (3) jenis aktivitas responden dalam facebook; dan 
(4) tanggapan responden terhadap pemanfaatan facebook dan blog untuk pembelajaran. Bagian 1 mengumpulkan informasi tentang nama, nomor induk mahasiswa (NIM), usia, jenis kelamin, serta semester responden, Bagian 2 berisi pertanyaan pilihan ganda tentang kepemilikan responden terhadap blog dan facebook. Bagian 3 mengumpulkan informasi tentang aktivitas responden dalam memanfaatkan facebook dimana responden diminta menandai pilihan aktivitas. Bagian 4 mengumpulkan informasi tentang aktivitas responden dalam facebook yang terkait dengan pembelajaran. Bagian 5 mengumpulkan informasi tanggapan atau persepsi responden terhadap efektivitas model untuk kegiatan pembelajaran dalam bentuk skala Likert 5 angka.

Kuesioner Bagian 5 telah diuji keshahihan (validitas) dan kehandalannya (reliabilitas). Uji kesahihan dilakukan dengan melihat koefisien korelasi product moment, sedangkan uji kehandalan dilakukan dengan Cronbach alpha $(\alpha)$. Didapat angka korelasi masing-masing di atas 0.6 sehingga disimpulkan bahwa instrumen tersebut sahih. Nilai $\alpha$ pada uji kehandalan diperoleh angka 0,769 yang menunjukkan bahwa kuesioner tersebut handal. Dengan demikian, kuesioner dapat dipergunakan.

\section{HASIL DAN PEMBAHASAN}

Hasil

Seluruh responden menyatakan bahwa mereka memiliki account facebook. Temuan ini menunjukkan bahwa facebook memang media sosial yang paling popular di kalangan mahasiswa, khususnya mahasiswa Fakultas Bahasa Universitas Islam Sultan Agung Semarang. Tujuh puluh empat persen responden juga menyatakan bahwa mereka mempunyai account jejaring sosial lainnya, seperti Twitter. Hal ini berarti sebagian besar mahasiswa memiliki dan mengoperasikan lebih dari 1 jejaring sosial. Kondisi ini memberikan peluang yang lebih besar lagi kepada mahasiswa untuk berinteraksi dengan lebih banyak kalangan dengan kelom- pok peminatan (interest) yang beragam. Sebagian besar responden menghabiskan antara 1 s.d. 2 jam perhari.

Berkaitan dengan kepemilikan weblog, diperoleh data bahwa hanya $42 \%$ responden (23 mahasiswa) yang memiliki weblog. Dari jumlah tersebut, hanya 3 orang mahasiswa yang mengaku aktif memperbarui blognya. Dengan demikian, ada perbedaan yang besar antara jumlah mahasiswa yang memiliki blog dan yang aktif memperbaruinya.

Untuk mengetahui aktivitas yang sering dilakukan responden dengan facebook-nya, peneliti memberikan 16 aktivitas untuk dipilih seperti bermain games, memperbarui (update) status, berbagi tautan, mencari informasi, menulis pesan, memberi tanggapan atau komentar, berdiskusi dengan teman, mengikuti berita, dan lain-lain. Responden memilih sebanyak aktivitas yang mereka sering lakukan ketika menggunakan facebook. Hasilnya menunjukkan bahwa aktivitas yang paling banyak dilakukan adalah mencari informasi. Aktivitas ini dipilih oleh sebanyak 40 orang responden. Aktivitas selanjutnya adalah mengikuti berita yang dipilih oleh sebanyak 39 responden, mengobrol (chatting) dipilih oleh 33 responden, dan memberi komentar yang dipilih oleh 30 responden. Diagram 1 menggambarkan selengkapnya aktivitas yang dilakukan responden dengan facebook.

Terkait dengan aktivitas responden dalam facebook group yang dibuat untuk kegiatan pembelajaran, peneliti memberikan 9 alternatif aktivitas yang mungkin dilakukan oleh responden. Bentuk aktivitas tersebut di antaranya posting topik, memberi komentar, mengunggah materi, mengunduh materi, dan mengerjakan quiz. Hasilnya menunjukkan bahwa 5 aktivitas yang paling banyak dipilih adalah mengunduh materi, diikuti dengan memberi komentar, berdiskusi, dan mengikuti tautan (links). Diagram 2 menggambarkan selengkapnya aktivitas responden dalam facebook group yang terkait dengan pembelajaran. 


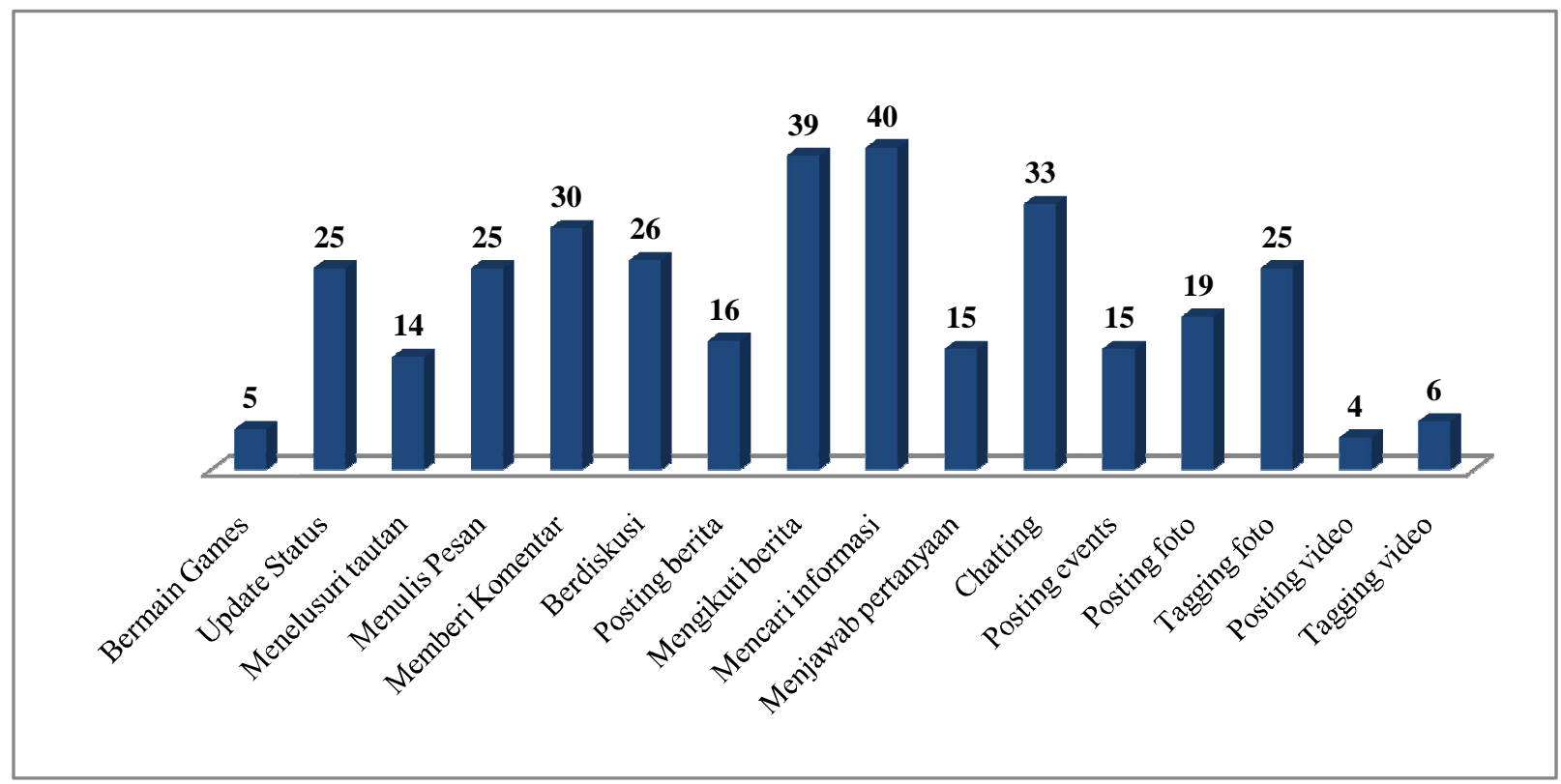

Diagram1. Aktivitas Responden yang Dilakukan di Facebook

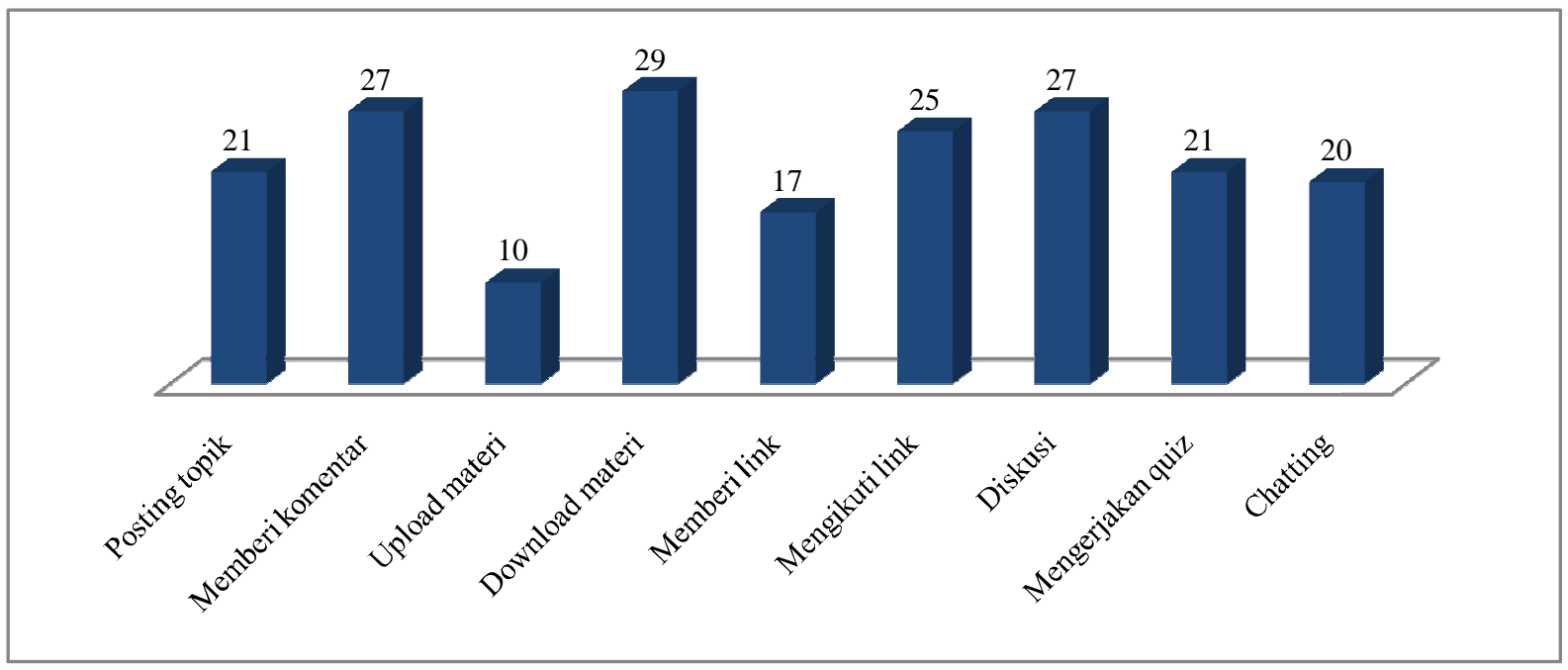

Diagram 2. Aktifitas Pemanfaatan Facebook untuk Pembelajaran

Efektivitas model ini untuk pembelajaran diukur dengan data mengenai tanggapan/persepsi responden. Penilaian efektivitas dilihat dari empat dimensi, yaitu (1) akses terhadap materi perkuliahan; 2) akses untuk bertanya dan atau menanggapi pertanyaan; 3) akses untuk bertukar pendapat atau diskusi; dan 4) dampak. Dimensi 1 mencakup indikator-indikator (1) dapat mengakses materi perkuliahan dengan mudah; (2) dapat berbagi materi perkuliahan; (3) kesempatan untuk mengetahui informasi perkuliahan secara lebih cepat; dan (4) kesempatan untuk membaca dan mempelajari materi per- kuliahan lebih besar. Dimensi 2 mencakup indikator-indikator (1) adanya kesempatan bertanya kepada dosen dan teman (mahasiswa); (2) dapat menjawab atau menjelaskan pertanyaan; (3) dapat menjawab pertanyaan lebih mudah; dan (4) keleluasaan untuk bertanya atau menjawab pertanyaan. Dimensi 3 mencakup indikator-indikator: (1) peluang untuk bertukar pendapat dengan dosen dan teman mahasiswa; (2) mengikuti diskusi yang dilakukan dosen/mahasiswa; (3) menyenangkan; dan (4) dapat dilakukan dengan mudah. Dimensi 4 mencakup indikator (1) meningkatan kualitas pembelajaran; dan (2) 
memperkaya pembelajaran di ruang kelas. Responden memberi tanggapan dengan angka 1 yang menunjukkan sikap Sangat Tidak Setuju sampai dengan angka 5 yang menunjukkan Sangat Setuju. Hasilnya dapat dilihat pada Tabel 1.

\section{Tabel 1. Rerata Skor}

\begin{tabular}{lc}
\hline \multicolumn{1}{c}{ Dimensi } & Rerata Skor \\
\hline Akses terhadap materi perkuliahan & 3,76 \\
Akses untuk bertanya dan atau & 3,66 \\
menanggapi pertanyaan & \\
Akses untuk bertukar pendapat atau & 3,66 \\
diskusi & \\
Dampak & 3,72 \\
\hline
\end{tabular}

\section{Pembahasan}

Temuan penelitian ini sesuai dengan penelitian sebelumnya yang dilakukan Petrovic dkk. (2012), Junco (2011), dan Alhenshiri (2011) yang menyatakan bahwa facebook adalah media sosial yang paling populer di antara anak muda dan mahasiswa. Penelitian ini bahkan menemukan bahwa 100\% responden memiliki facebook dan menggunakannnya untuk berbagai kegiatan. Namun, penelitian ini berbeda dengan Alhenshiri (2011) yang menyimpulkan bahwa meski mahasiswa menggunakan facebook rutin setiap hari, tetapi mereka lebih tertarik akan aspek sosial dari facebook dibandingkan dengan aktivitas pemerolehan pengetahuan.

Penelitian ini memang menemukan bahwa kegiatan seperti memperbarui (update) status, obrolan (chatting), memasang foto, bermain games, dan lain-lain tetap dilakukan. Se- lain itu, responden juga melakukan aktivitas yang terkait dengan pemerolehan pengetahuan seperti mengunduh materi pembelajaran, mengikuti tautan yang relevan dengan materi perkuliahan, berdiskusi dan mengerjakan kuiz. Sebagai contoh, ketika peneliti melontarkan pertanyaan tentang manfaat pembelajaran grammar dalam pemerolehan bahasa kedua (the role of teaching grammar) dan meminta mahasiswa menanggapi, terjadi 21 tanggapan dari mahasiswa dan 4 tanggapan balik dari dosen yang berlangsung selama 6 hari sejak pertanyaan tersebut dilontarkan sebagaimana ditunjukkan Gambar 1 .

Komentar mahasiswa juga sangat beragam, tetapi tetap relevan dengan pertanyaan yang diajukan. Hal ini menandakan bahwa mereka benar-benar terlibat dalam usaha pemerolehan ilmu pengetahuan. Sebagai contoh, seorang mahasiswa berinisial MA menulis komentar seperti berikut.

"In my opinion grammar is important, but in
learning english shoulbe emphasized on prac-
tice speaking, in indonesia learning english
begin from elementary school till senior high
school, but after they graduated from it, many
students are not fluent in english, i think it's
caused by they doubt to speak because they
are confused about grammar, so the conclu-
sion is grammar is important but the teacher
should be emphasized on the grammar, and
teach the student dont be scared about gram-
matical error,is not the meaning of communi-
cation is understanding each other?"

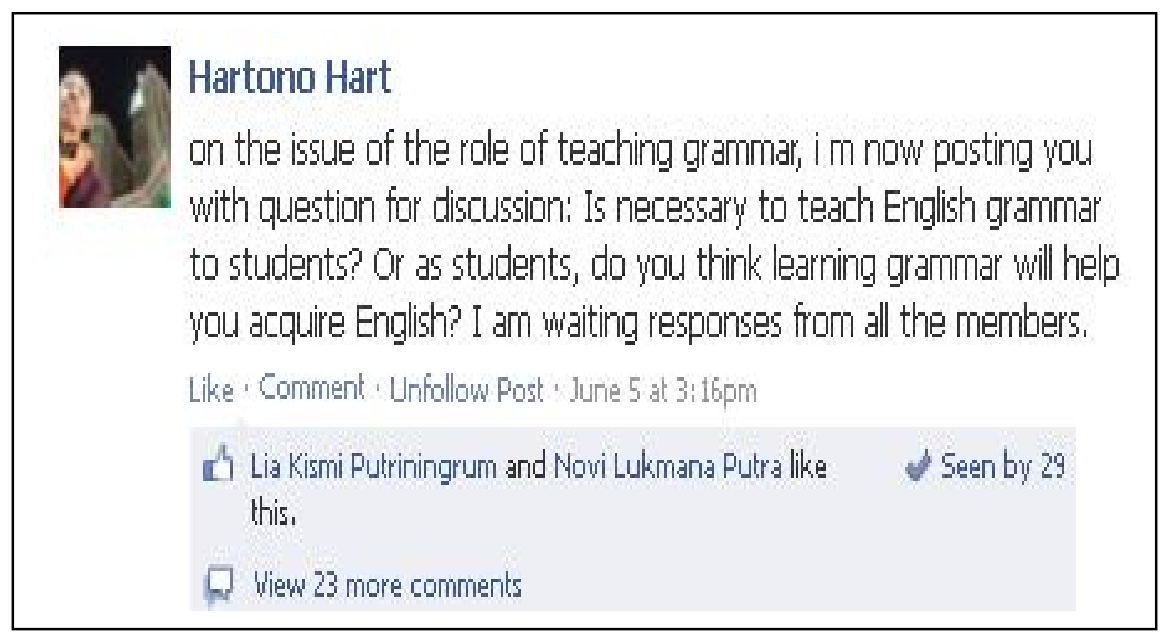

Gambar 1. Jumlah Komentar/Tanggapan terhadap Pertanyaan Dosen 
Seorang mahasiswa lain dengan inisial IA menulis komentar seperti berikut.

"In my opinion, grammar is the main of English structure, and of course it is important, because it can help us not only acquiring but also improve capability in English, just imagine if somebody who want learn English, but they do not understand about grammar? seems like hungry but have nothing to eat. so, absolutely grammar is needed sir. Thanks"

Temuan penelitian ini sejalan dengan Lim \& Ismail (2010) yang menemukan bahwa facebook memiliki potensi untuk dipergunakan sebagai media diskusi akademik dalam jaringan. Ellison \& Wu (2008) juga menyatakan bahwa blog membantu pengembangan wawasan yang lebih luas antarmahasiswa melalui interaksi. Interaksi ini pula yang akan memunculkan pembelajaran multilevel.

Meskipun hasil perhitungan rerata skor hanya berkisar antara 3,6 s.d. 3,7, model ini dapat dikatakan efektif karena responden menyetujui bahwa model ini bisa menambah akses mereka terhadap materi perkuliahan, akses untuk bertanya dan menanggapi pertanyaan, akses untuk bertukar pendapat, serta berdampak positif terhadap pembelajaran. Pertukaran pendapat terjadi tidak hanya antara dosen dan mahasiswa, tetapi juga antarmahasiswa. Berikut adalah contoh diskusi yang terjadi antara mahasiswa dengan initial MAK dan MA.

MAK : I don't agree whit beta. from my opinion, English is a tool to communicate, if we use the English language without grammar your language doesn't be understood by others, may be we are doing wrong speech in every speech, before using English language we need to know about the basis of Grammar or study about grammar first.

MA : I agree with beta bos Muh Anwar Kholil as far it can be understood even though the grammar is false, $i$ think it's no problem, and that's what we call by language, hahaha
MAK : boz alfan, if your speech can,t understood whit the some one about wrong grammar what about your opinion if you just memorize about focabularis. mr alfan

MA : I think from the vocab it can be understood, for example 'last night i go to mini market' in grammar that's wrong sentence but in meaning.

\section{PENUTUP}

Media jejaring sosial facebook masih menjadi media jejaring sosial yang paling popular di kalangan mahasiswa. Mahasiswa menggunakan media ini untuk berbagai kegiatan, baik yang bersifat sosial semata maupun yang terkait dengan kegiatan pembelajaran. Weblog dan facebook dapat dipergunakan sebagai media pembelajaran, baik secara terpisah maupun secara terintegrasi. Pada penelitian ini, weblog dan facebook diintegrasikan penggunaannya. Dosen mengunggah materi perkuliahan di blog dosen sekaligus memberikan tautan-tautan terhadap materi yang relevan dengan topik. Selanjutnya, komentar, diskusi, pertanyaan dan lainlain dilakukan lewat facebook group. Hasil penelitian menunjukkan bahwa media ini efektif dalam pembelajaran. Hal tersebut dapat dilihat dari partisipasi mahasiswa dalam bentuk pemberian komentar, diskusi yang berlangsung, serta kuesioner. Media ini memberi akses kepada mahasiswa berkaitan dengan materi pembelajaran, diskusi,dan lain-lain yang pada akhirnya akan meningkatkan kualitas pembelajaran.

\section{UCAPAN TERIMA KASIH}

Artikel ini dikembangkan dari penelitian yang berjudul "Pengembangan Model ELearning Berbasis Weblog dan Facebook untuk Meningkatkan Kualitas Pembelajaran di Perguruan Tinggi" yang dibiayai oleh Dikti pada Tahun 2012/2013. Untuk itu, penulis mengucapkan terima kasih kepada DIKTI, Kopertis Wilayah 6, serta LPP UNISSULA. 


\section{DAFTAR PUSTAKA}

Alhenshiri, A. 2011. "Exploring the Use of Facebook in Education: Promising, yet more Work is Needed". FOCUS Vol. 19 (3) .

Deng, L. \& Tavares, N. J. 2013. "From Moodle to Facebook: Exploring Students' Motivation and Experiences in Online Communities". Computer \& Education 68, pp.167-176.

Ellison, N., \& Wu, Y. 2008. "Blogging in the Classroom: A Preliminary Exploration of Student Attitude and Impact on Comprehension". Journal of Education Multimedia and Hypermedia 17 (1), pp. 99122.

Flatley, M. 2005. "Blogging for Enhanced Teaching and Learning". Business and Communication Quarterly. 68, pp.77-80.

Gall, J. P., Gall, M., \& Borg, W. R. 2005. Applying Educational Research. Pearson Educaton Inc.

Huffaker, D. 2005. "The Educated Blogger: Using Weblogs to Promote Literacy in the Classroom". AACE Journal Vol 13 (2), pp.91-98.

Junco, R. 2011. "The Relationship between Frequency of Facebook Use, Participation in Facebook Activities, and Student Engagement". Computer \& Education 58. pp. 162-171.

Lim, T., \& Ismail, J. T. 2010. "The Use of Facebook for Online Discussion among Distance Learners". Turkish Online Journal of Distance Education (TOJDE) Vol. 11 (4).

Lim, T., \& Ismail, J. T. 2010. "The Use of Facebook for Online Discussion among Distance Learners". Turkish Online Journal of Distancce Education (TOJDE) Vol.11(4).
Pascu, C. 2008. An Empirical Analysis of the Creation, Use and Adoption of Social Computing Application: IPTS Exploratory Research on Social Computing. Diunduh pada 7 Januari. http://ftp.jrc.es/EURdoc/JRC46431.pdf, 2013.

Petrovic, N., Petrovic, D., \& Jeremic, V. 2012. Possible Educational Use of Facebook in Higher Environmental Education. ICICTE.

Phillips, S. 2007. A Brf History of Facebook. The Guardian .

Pollara, P., \& Zhu, J. 2011. "Socail Networking and Education: Using Facebook as an Edusocial Space . Proceeding of Society for Information Technology \& Teacher Education International Conference (hal. 3330-3338). Chesapeake.

Robert, D., Foehr, u., \& Rideout, V. 2005. Generation M: Media in the Lives of 8-18 year olds. Dipetik July 25, 2012, dari Henry J. Kaiser Family Foundation: www.kff.org/entmedia/7251.cfm

Selwyn, N. 2007. Screw Blackboard ... do it on Facebook. Dipetik August 18, 2012, dari Startrek Digital Literacy: startrekdigitalliteracy.pbworks.com/f/2g19b89ezl6ursp 6e749.pdf.

Top, Siah E. 2012. Blogging as a Social Medium in Undergraduate Courses: Sense of Community Best Predictor of Perceived Learning. Internet and Higher Education 15, pp. 24-28.

Williams, J., \& Jacobs, J. 2004. "Exploring the Use of Blogs as Learning Spaces in the Higher Education Sector". Australian Journal of Educatation Technology 20 (2), pp. 232-247. 